\title{
レーザーオリジナル 4
}

\author{
均一電子ビーム励起大容量エキシマー \\ レーザー装置
}

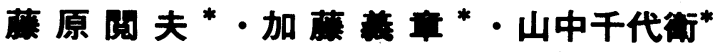

\author{
（1980年11月29日 受理） \\ Electron-Beam Pumped Excimer Laser Device for \\ Uniform, Large Volume Excitation \\ Etsuo FUJIWARA*, Yoshiaki KATO*, and Chiyoe YAMANAKA*
}

(Received November 29, 1980)

\begin{abstract}
Coaxial diode electron-beam device for excimer laser pumping has been designed and and constructed. In designing this device, we have especially considered spatial uniformity of energy deposition, pumping efficiency and electron-beam pinch. Experimental observation on diode impedance, beam pinch, and energy deposition uniformity are compar. ed with standard formula or a code aclculation on electron transporı.
\end{abstract}

\section{1.はじめに}

希ガスハロゲンエキシマーレーザーはレーザ 一核融合や同位体分離などのエネルギー開発, 光化学, マイクロエレクトロニクス加工或いは $\mathrm{N}_{2}$ レーザーに変わる色素レーザー励起光源など 多種多様な応用の可能性を秘めている。 $\mathrm{KrF}$ 一ザー $(249 \mathrm{~nm})$ に代表されるこの種のレーザー の励起方法は放電励起と電子ビーム励起に大別 される。この中で放電励起レーザーは安価で手 軽な反面，大きな体積にわたって均一に安定な 放電を得ることが難しく高出力化は困難である。 他方電子ビーム励起レーザーの場合, 装置が大 掛りになる事を省けば容易にスケールアップが 可能で高出力パルス動作に適している。レーザ 一効率に関しては紫外線又は X 線予備電離 $\mathrm{KrF}$
レーザーの $1 \%$ 前後 ${ }^{1}$ の効率に対して, 電子ビー ム励起の場合ガス中に注入されたエネルギー比 で $9 \%$ 効率2)が報告されている。

我々は電子ビーム励起レーザー装置の高出力 ・高効率化に関する問題点を明らかにするため に，装置を試作し，增幅特性の測定を行ってき た。これと平行してアノード膜及びレーザー気 体中での電子ビーム伝搬の様子をモンテカルロ シミュレーションコードを用いて解析し ${ }^{3}$, これ にもとずいて装置の改良を行った。これらの過 程で電子ビーム励起気体レーザー装置の設計 · 製作・動作特性に関するいくつかの知見が得ら れた。本論文ではこれらのうち技術的な問題を 中心に報告し，将来エキシマーレーザーを高出 力化する際の参考資料として供したい。

* 大阪大学レーザー核融合研究センター（テ565 吹田市山田上）

* Institute of Laser Engineering, Osaka University (Yamadakami, Suita, Osaka 565) 


\section{2. 雪子ビーム励起エキシマーレーザー装是 の設諎}

\section{1 基本設計}

電子ビーム励起レーザー装置は使用目的によ り大きく 3 種類に分類できる。すなわち(1)マル クス電源の出力をダイオードに直結する方式い, (2)マルクス電源にインダクタンスの小さいコン デンサーを多数使って同軸構造の P F N(Pulse Forming Network) 回路を構成し, 数10ns程度 のパルス幅を得る方式5), 及び(3)マルクス電源の 出力を一旦低インピーダンスのパルス整形ライ ンに移し、その後ダイオードに導く方式6である。 (1)は約 $500 \mathrm{~ns} \sim 3 \mu \mathrm{s}$ の高エネルギー励起に，(2)は コンパクトな短パルス低エネルギー励起（ $\leqslant 1$ kJ) に，また(3)は短パルス・高エネルギー励起 （ $\geqq 1 \mathrm{~kJ} ）$ に適している。またダイオード形状に ついても 3 種類に大別でき，(1)平面アノードを 通して電子ビームを光軸の横方向から照射する タイプク,(2)やはり横方向励起であるがカソード とアノードをシリンドリカルな同軸構造とし， 回りから照射するタイプ8),(3)光軸方向から電子 ビームを強い磁場でガイドして打ち込むタイプ9 などである。この中で(1)は一方向のみの場合に は励起の均一性が悪いので 2 方向から電子ビー ムを照射する必要があり，また(3)は複雑な構造 のガイド磁場を必要とする。これらに比べて(2) は単一電源で均一な励起が容易に得られ，また アノード表面での電子ビーム電流密度を最も小 さくできる特長がある。

我々はできるだけ大容量のレーザー気体を短 パルス電子ビームで均一に励起し得る装置の開 発を目的として，パルス整形ラインを有する同 軸ダイオード構造を選んだ。装置の全体構成の

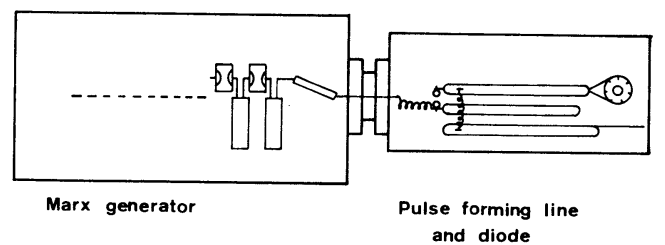

Fig. 1 Coaxial diode electron-beam device for excimer laser pumping.
概念図をFig. 1 に示す。マルクス電源に蓄えら れた電気エネルギーによってパルス整形ライン を充電し，その形状によって決る高電圧短パル スを電子ビームに変換する。電子ビームは陽極 を兼ねた金属薄膜を透過して後方のレーザー気 体を励起する。この様な電子ビーム励起レーザ 一を設計する場合, レーザー特性, 装置全体の エネルギー利用効率, 高電圧パルス技術等に関 する諸問題を考虑する必要があるが，我々は特 に下記の点に注意して装置設計を行なった。

（1）均一なレーザーパターンを得るために, 励起をレーザーガス全体にわたってできる だけ一様にする。

（2）電子ビームはアノード膜透過過程で散乱 やエネルギー損失を受け，またレーザー気 体中においても多くの衝突・散乱を繰り返 してその運動エネルギーを失って行く。そ こで膜での損失も考虑して, 入射電子ビー ムエネルギーをレーザー気体の励起に有効 に利用する。

（3）大電流動作に伴う自己磁場により電子ビ 一ムがセルフピンチを起し, 励起の均一性 が失われるので, ピンチ領域以下の電流で 動作させる。

\section{2 設計の詳細と製作}

装置の製作と特性測定は 2 段階に分けて行っ た。第 1 の段階では同軸型ダイオードのアノー ドの直径を $12 \mathrm{~mm}$ とし,第 2 の段階ではこれを 100 $\mathrm{mm}$ としたこれに伴ってパルス整形ラインの構 造もやや変更したので，以下これらを区別する ため, 前者 $(12 \mathrm{~mm} \phi)$ を I 型, 後者 $(100 \mathrm{~mm} \phi)$ をII 型とする。

\section{2 .1 マルクス電源}

本装置に使用したマルクス電源のブロック図 をFig. 2 に示す。マルクス電源は土50kV充電で $0.3+0.3 \mu \mathrm{F}$ のオイルコンデンサー 7 段からなり, 最大出力電圧は $700 \mathrm{kV}$, この時の蓄積エネルギ 一は5.25kJである。スイッチは 7 段の $\mathrm{SF}_{6}$ ガス ギャップであり，全段トリガー方式のため自爆 


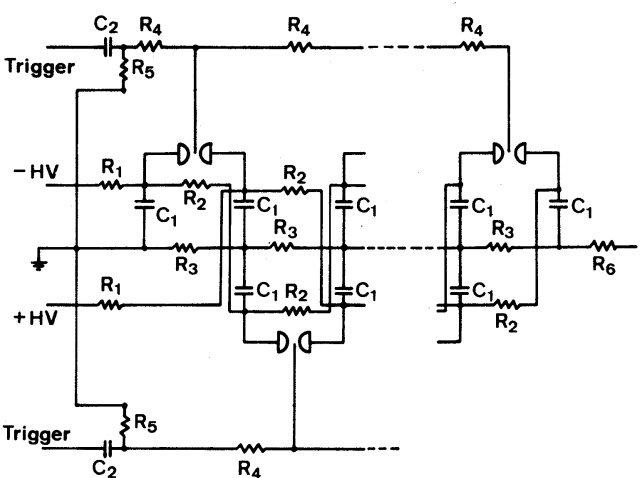

Fig. 2 Circuit diagram of the Marx generator.

電圧よりかなり低い電圧でも安定に動作させる ことができる。またジッターは充電電圧が士20 ～50kVの範囲で50ns 以内が得られている。全 イ ンダクタンスは $4.9 \mu \mathrm{H}$ であり, マルクス電源か らパルス整形ラインへの充電時間は $0.5 \mu \mathrm{s}$ である。

\section{2 .2 パルス整形ライン}

パルス整形ラインはマルクス電源で発生した 電圧・電流パルスを一旦伝送線路を兼ねたコン デンサーに蓄え，ここでコンデンサーの形状に よって決るパルス幅とインピーダンスにパルス 整形する部分である。Fig. 3 にパルス整形ライ ン及びダイオード部の略図を示す。パルス整形 ラインはインピーダンスを変えることが容易な 平行平板型のブルムライン回路を採用した。充 電々圧がピーク值の 8 〜 割に達した時, 自爆 タイプの主スイッチが動作し，これにより発生 した電圧・電流パルスはナイフエッジ型のプレ パルススイッチを通ってダイオード部に印加さ れる。ブルムラインの誘電体としては純水（比 誘電率80）を用いており，イオン交換樹脂によ り非イオン化され常時循環によって比抵抗が 1 $\mathrm{M} \Omega \mathrm{cm}$ 以上に保たれている。水の絶縁破壊強度 は実験的にJ. C. Martin ${ }^{10)} に よ り$ 次式で与えら れた。

$$
\text { E } t^{1 / 3} A^{1 / 10}=k
$$

ここで $E$ は電界強度で $\mathrm{MV} / \mathrm{cm}, t$ は電圧の印加 時間で $\mu \mathrm{s}, A$ は表面積で $\mathrm{cm}^{2}$ 単位で与えられこ
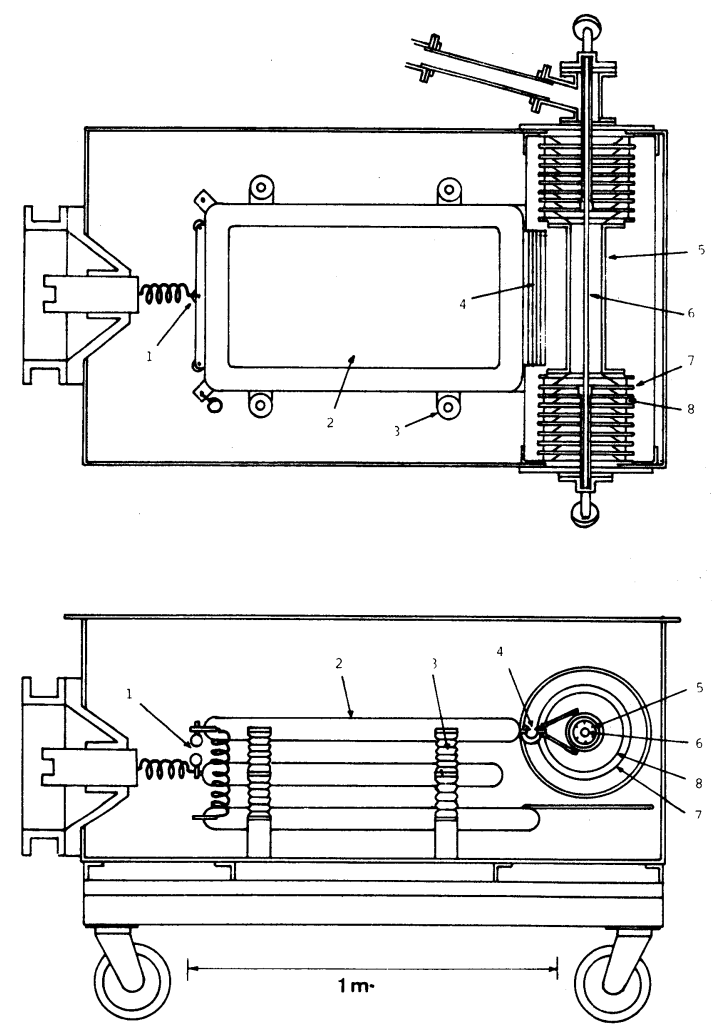

Fig. 3 Blumlein type parallel plane pulse forming line and coaxial diode. 1. Main switch 2. Parallel plane capacitor 3. Insulator 4. Prepulse switch 5. Cathode 6. Anode 7. Metal grading rings 8 . Acrylic insulator rings.

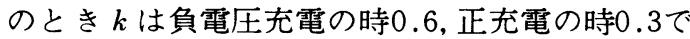
ある。コンデンサーは幅 $50 \mathrm{~cm}$ 長さ $80 \mathrm{~cm}$ でその電 極間隔は容易に変更でき，I 型では $6 \mathrm{~cm} ，$ II 型 では $5 \mathrm{~cm}$ である。また導体端末においては電界 集中がおこり，これを防止するため曲率半径 3 $\mathrm{cm}$ の電界緩和コロナリングを設けた。コロナリ ングを近似的に円筒対円筒と考えると, 電界 $E_{\mathrm{m}}$ は $\quad E_{\mathrm{m}}=f V / D$

ここで $V$ は印加電圧， $D$ は電極間隔であり， $f$ は次式により与えられる。

$$
f=\frac{\sqrt{(D / r)^{2}+4 D / r}}{2 \ln \left[D / 2 r+1+\frac{1}{2} \sqrt{\left.(D / r)^{2}+4 D / r\right]}\right.}
$$

ここで $r$ は円筒半径で, II型に対して $f=1.265$ と計算される。 $400 \mathrm{kV}$ 正充電の場合, 端末での 
絶縁破壊時間は II 型では3. $5 \mu \mathrm{s}$ と計算され，充 電時間の $0.5 \mu \mathrm{s}$ に比べて十分長い。平行平板コ ンデンサーの容量は I 型では $5.9+5.9 \mathrm{nF}$, II 型 では6.8+6.8nFでインピーダンスはそれぞれ 9 $\Omega$ 及び7.7 $\Omega$ である。またパルス幅の設計値は共 に50nsである。

主スイッチはI 型では水中の自爆タイプであ ったが, 動作時の水中でのショック波が大きく 絶縁ボルトなど弱い部分を破損する事があり，

II型では取扱いの容易な $\mathrm{SF}_{6}$ ガススイッチタイ プに改めた。またI 型の負充電を开型では正充 電に変更し、これに伴って主スイッチの位置を 接地電極と中間電極の間に移動させて外部トリ ガーを行い易い様にした。

\section{2 .3 ダイオード}

通常の電子ビーム発生装置ではパルス整形ラ インとダイオード部を分離する構造が取られる が, 同軸ダイオードの場合, この構造では, カ ソードと外壁との絶縁のためにダイオード部は 大きな容積を必要とする。我々はダイオード部 をパルス整形ラインと共に水槽に入れ, 純水に よって絶縁を持たせてコンパクト化を計った。 ダイオード部は電子ビーム発生領域とレーザー 気体励起領域を含んでいて, レーザーの性能に 直接影響を及ぼす部分である。励起の空間的均 一性と電子ビームエネルギーの有効利用につい ては我々の作成した電子ビーム伝搬コード3) で シミュレーションした。ா型のダイオードの場 合の励起の空間分布のシミュレーション結果を Fig. 4 に示す。これから電子ビームエネルギー が400kV及び500kVにおいて中心附近がやや強 いがかなり均一な励起が可能である。次に電子 ビームのエネルギー利用効率に関するシミュレ ーション結果をFig. 5 に示す。ここでRはアノ 一ド半径, $\mathrm{P}$ は気体圧力であり, アノード膜に 入射する電子ビームエネルギーの内でレーザー 気体中で失われるエネルギーの割合を表わして

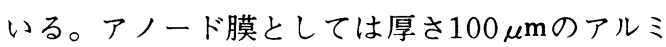
ニウムを想定している。図で破線部分は励起の 空間的均一性が失われる領域である。エネルギ

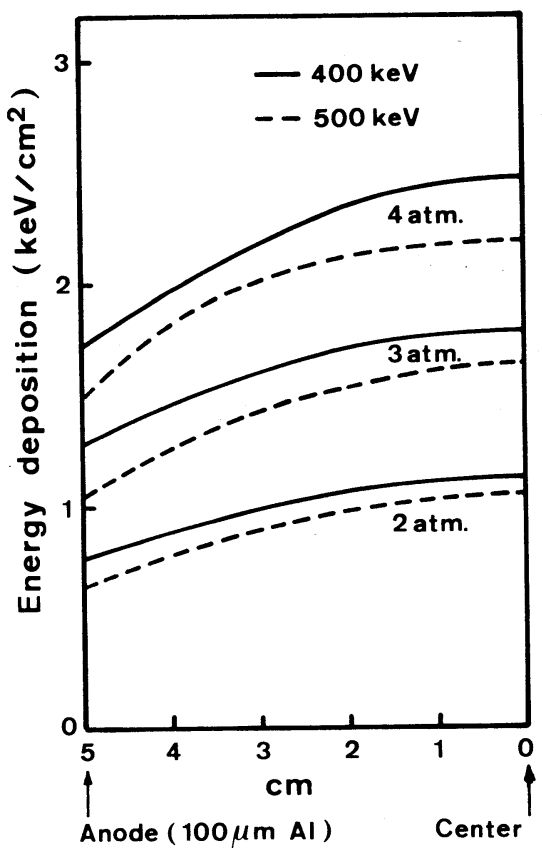

Fig. 4 Energy deposition profile for cylindrical electron-beam excitation. The gas mixture is $94 \%$ argon and $6 \%$ krypton.

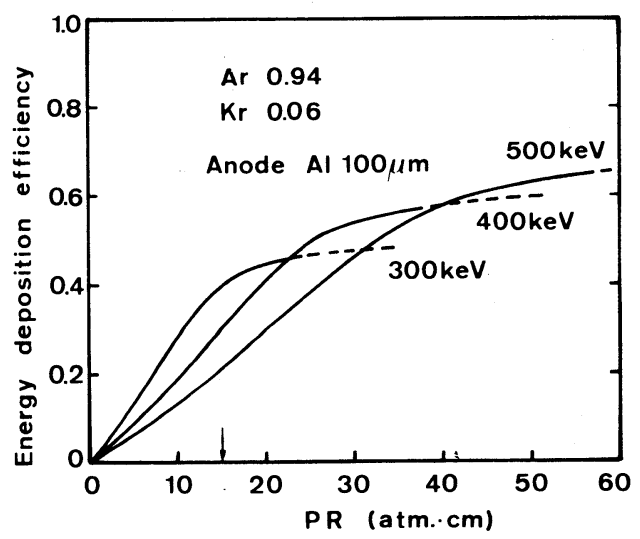

Fig. 5 Energe deposition efficiency of electronbeam in the laser gas as a function of $P R$ where $P$ is gas pressure and $R$ is anode radius. The arrow shows the design value for operation.

一利用効率はI 型では直径が小さいために $1 \%$ 以下と非常に小さいのに比べて， II 型では最大 圧力 3 気圧を予定していて（矢印）計算結果か ら $400 \mathrm{kV}$ 動作で30\%が期待できる。ガス中の蓄 積エネルギーの視点からは $300 \mathrm{kV}$ 動作に比べて 
$400 \mathrm{kV}$ 動作の場合は $33 \%$ 増加し，また $400 \mathrm{kV}$ 動 作に比べて $500 \mathrm{kV}$ 動作は $9 \%$ の増加に留まるた め, II 型の動作電圧を $400 \mathrm{kV}$ に設定した。

またビームピンチは電子ビーム電流に上限を 与える重要な問題である。電子ビームは自己磁 場によりその軌道を曲げられ，アノードに斜め に入射する。同軸構造の場合自己磁場は電子ビ 一ムの両端で最も強くなり, 両端での電子ビー ムのアノード入射角度 $\theta$ は次式で与えられる ${ }^{11}$ 。

$$
\sin \theta=-\frac{e \mu_{\mathrm{o}}}{4 \pi m c} \frac{I}{\gamma \beta} \ln \frac{r_{\mathrm{a}}}{r_{\mathrm{c}}}
$$

ここで $\beta=v / c, \gamma=1 / \sqrt{1-\beta^{2}}$ である。 最大電流として $\theta=90$ 度（水平入射）の場合を Fig. 6 に示す。ここで $r_{a}$ はアノード半径， $r_{c}$ は カソード半径であり, 図で $\triangle$ 印は I 型の，また ○印はII型の設計值を示している。

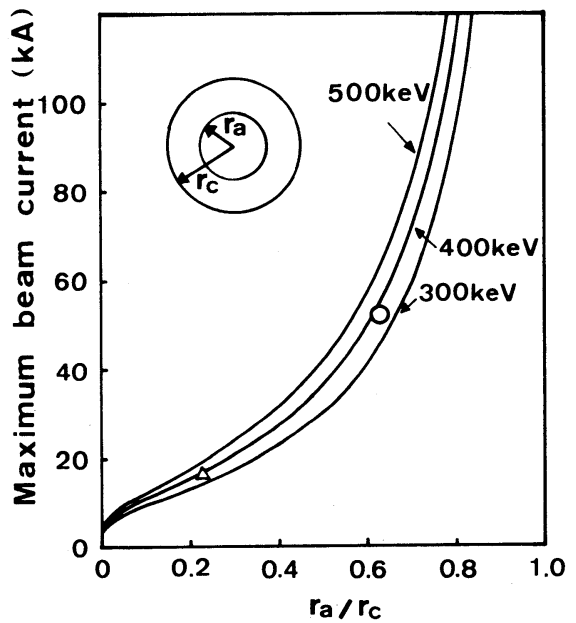

Fig. 6 Maximum electron-beam current limited by beam pinch for cylindrical pumping geometry. The ordinate is the ratio of radii of anode and cathode.

次に具体的な形状について以下に述べよう。 Fig. 7 はII型のダイオード部の断面を示す。電 子ビーム発生部は約 $10^{-4}$ torr $の$ 真空に保たれて いる。カソード材料は I 型ではチタン $25 \mu \mathrm{m} を$ 使用したが， II 型では寿命などの点 ${ }^{12)}$ から炭素 織維を用いた。炭素繊維は切断面をアノードに 向けて取り付けている。アノードに関しては, I 型では厚さ $50 \mu \mathrm{m}$ 及び $100 \mu \mathrm{m}$ のタンシートを

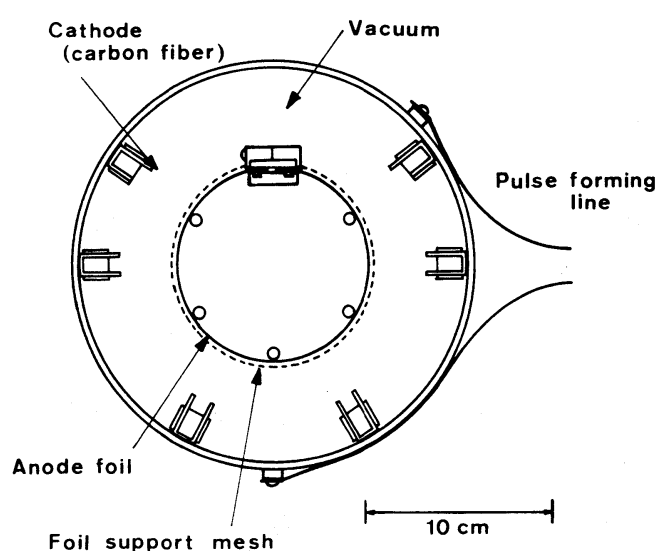

Fig. 7 Cross section of the coaxial diode (Type II),

電子ビーム溶接によって長さ $50 \mathrm{~cm}$ 直径 $12 \mathrm{~mm}$ (有 効径 $10 \mathrm{~mm})$ のパイプ状に溶接したものを使用し た。他方 II 型では励起体積の増加を計ってア， 一ドの直径を $10 \mathrm{~cm}$ (有効径 $8.5 \mathrm{~cm}$ ) とし, 材料と してアルミニウム $100 \mu \mathrm{m}$ を使用している。Fig. 7 に示す様にアルミニウムシートを円筒状に丸 め, Oーリングで真空シールすることによりア ノードの低価格化を可能にした。また電子ビー 么溶接に比べて多種のアノード材料が選択でき， アノード膜の厚さの変更も容易である。またレ 一ザー気体の内圧による膜の張力はその直径に 比例して増加するため, 直径の小さい I 型では アノードの外部保持は不要であったが， I型で はアノード膜の外側を金属メッシュで覆って内 圧を支えている。

次にダイオードのインピーダンスについて述 べる。電子ビーム電流は空間電荷制限によって 決り, 非相対論的領域では Langmuir-Compt$\mathrm{on}^{13)}$ の次式で与えられる。

$$
\begin{aligned}
I & =1.47 \times 10^{4} \frac{V^{3 / 2}}{\eta^{2} r_{\mathrm{a}}} W \\
\eta & =\varepsilon-\frac{2}{5} \varepsilon^{2}+\frac{11}{120} \varepsilon^{3}-\cdots \ldots \ldots . . \\
\varepsilon & =\ln \left(r_{\mathrm{a}} / r_{\mathrm{c}}\right)
\end{aligned}
$$

ここで $W$ はビーム幅で電圧 $V$ は M V 単位である。 我々の装置ではカソードの回りから一様に電子 ビームが照射されるこのモデルと異なり刃状の 
ブレードから不均一に照射されるため，(5)式か ら決るアノード・カソード間隔より幾分短くし ている。

またカソードの絶縁に関しては角度30度（I 型）又は45度（而型）に切ったアクリルと金属 リングを交互に積み重ねた構造で, 金属リング によって強制的に均一電界分布になる様に工夫 されている。真空中でのアクリルの沿面放電耐 圧は角度45度に対してJ.C. Martinによって次 式で与えられている。

$$
\text { E } t^{1 / 6} A^{1 / 10}=175
$$

ここで $E$ は $\mathrm{kV} / \mathrm{cm}, t$ は $\mu \mathrm{s}, A$ は表面積で $\mathrm{cm}^{2}$ の単 位である。I 型では $2 \mathrm{~cm}$ 厚のアクリルを 9 段, II 型では 6 段で $400 \mathrm{kV}$ 動作において上式の耐圧 時間はそれぞれ $1.7 \mathrm{~ms}$ 及び $190 \mu \mathrm{s}$ である。

以上のI 型及びI型の諸設計值を Table 1に 示す。

Table 1 Designs of type I device and type II device.

\begin{tabular}{|c|c|c|}
\hline Pulse Forming Line & & \\
\hline Capacitor space & $6 \mathrm{~cm}$ & $5 \mathrm{~cm}$ \\
\hline Capacity & $5.9+5.9 \mathrm{nF}$ & $6.8+6.8 \mathrm{nF}$ \\
\hline Impedance & $9 \Omega$ & $7.7 \Omega$ \\
\hline Pulse width & $50 \mathrm{~ns}$ & $50 \mathrm{~ns}$ \\
\hline Blumlein switch & water gap & $\mathrm{SF}_{6}$ gas gap \\
\hline \multicolumn{3}{|l|}{ Diode } \\
\hline Cathode & Ti $25 \mu \mathrm{m}$ & carbon fiber \\
\hline Anode & $\mathrm{Ti} 50 \mu \mathrm{m}$ or $100 \mu \mathrm{m}$ & Al $100 \mu \mathrm{m}$ \\
\hline Anode diameter & $1.2 \mathrm{~cm}$ & $10 \mathrm{~cm}$ \\
\hline$A-K$ space & $20 \mathrm{~mm}$ & $30 \mathrm{~mm}$ \\
\hline Excitation length & $41 \mathrm{~cm}$ & $50 \mathrm{~cm}$ \\
\hline
\end{tabular}

\section{3. 功作特性の測定}

\section{1 耐電圧特性}

パルス整形ラインでのコンデンサーの耐電圧 は I， II 型共に十分な安全係数を取ってあるた め, 絶縁破壊といった事故は一度も発生してい ない。しかし例えば主スイッチとパルス整形ラ インとの結合部など電界集中の起り易い部分で は小さなアークが発生しやすく、 コロナリング によって電界集中を完全に防止する細心の注意 が必要である。またカソードの絶縁に関しても 沿面放電による事故は起っていない。しかしア
クリル表面が小さな沿面放電によって徐々に劣 化していくのが見られ，劣化の著しい絶縁体は 交換する必要があった。

\section{2 ダイオードインピーダンス}

ダイオード部の特性を調べるために，カソー ド電圧と電子ビーム電流をTektronix 7844 ニビ ームオシロスコープで観測した。電圧モニター は2 $\mathrm{k} \Omega$ の抵抗を通して流れる電流を出力 $1 \mathrm{~V} / \mathrm{A}$ の自己積分型ロゴスキーコイル(Ion Physics Company model CM-100-S) で測定した。ロ ゴスキーコイルの立上り応答時間は $10 \mathrm{~ns}$ である。 電流モニターはアノードを流れるリターン電流 をロゴスキーコイルで測定した。ここで使用し たロゴスキーコイルは文献(14)を参考にして製作 したもので，応答時間は $1 \mathrm{~ns}$ 以下といわれる。

Fig. 8 (a)，(b)はそれぞれI型と II型のカソー ド電圧, 電流及びインピーダンスを示す。I 型

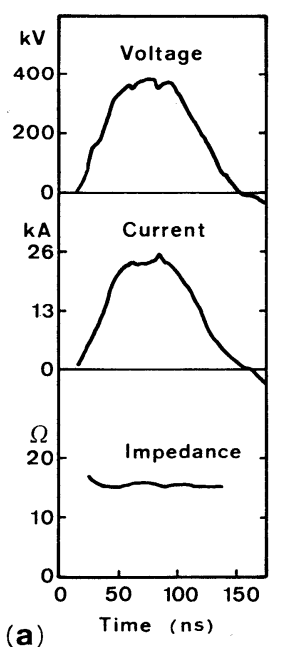

(a)

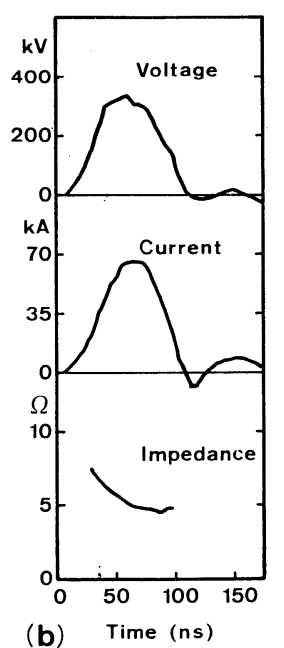

(b) Time (ns)
Fig. 8 Typical pulse forms of voltage and current. Also shown are temporal change of impedance calculated from these waveforms. (a) is for type I and (b) is for type II.

のアノード・カソード間隔は $20 \mathrm{~mm}$ でカソードの チタンブレード数は 8 枚である。他方(5)式から は同一の電流を得るにはその間隔は28mmと計算 され,これからブレードの様な局所的な電子ビ 一厶発生源に対しては(5)式で計算されるよりも 幾分間隔を小さくする必要があることがわかる。 
また炭素繊維をカソードに使った II 型でも同様 に計算との不一致が見られるが, 電子ビーム発 生面がチタンブレードに比較して広いために I 型ほど顕著ではない。インピーダンスに関して は I 型では電子ビーム発生時間にわたってほほ 一定で, このパルス幅ではカソードプラズマの 成長によるインピーダンス低下の影響は小さい

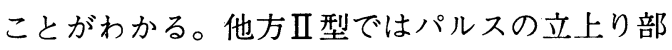
分でインピーダンスの低下が見られる。ここで 2 種のカソード材料を同一条件で比較した訳で はないので一概に優劣はつけられない。また, パルス整形ラインとダイオードとのインピーダ ンス整合が十分に取れない場合，電子ビーム照 射後にパルス整形ラインに残留しているエネル ギーがカソードプラズマによって短絡したアノ ード・カソード間でアーク電流として流れ,アノー ド膜を大きく破損する。完全にインピーダンス 整合を取ることは難しく，この対策としてカソ ードとアース間にインダクタンスを付けてアー ク電流を迂回させることによりその発生を防止 できた。

\section{3 ビームピンチ効果}

電子ビームのアノード膜透過後の軸方向分布 をラドカラーフィルム（日東電工）で測定した。 I 型及びПI 型での一例をそれぞれ Fig. $9(\mathrm{a})$ ，

(b)に示す。（a）においてアノードパイプの中心 で電子ビームの透過が見られないのは, ここが 2 本のチタンチューブの結合部に当る為である。 軸方向分布は中心附近に強い強度分布が見られ

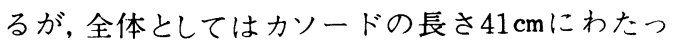
て一様な電子ビーム照射が得られている。中心 附近が強い原因はビームピンチの影響と思われ る。II型での測定結果 Fig. 9(b) は電子ビーム装 置をビームピンチ領域で動作させたため, その 影響を顕著に表わしていてカソード長 $50 \mathrm{~cm}$ に対 して電子ビーム透過が見られるのは約 $30 \mathrm{~cm}$ と短 くなっている。

3. 4 アノード断面の電子ビーム励起強度 分布
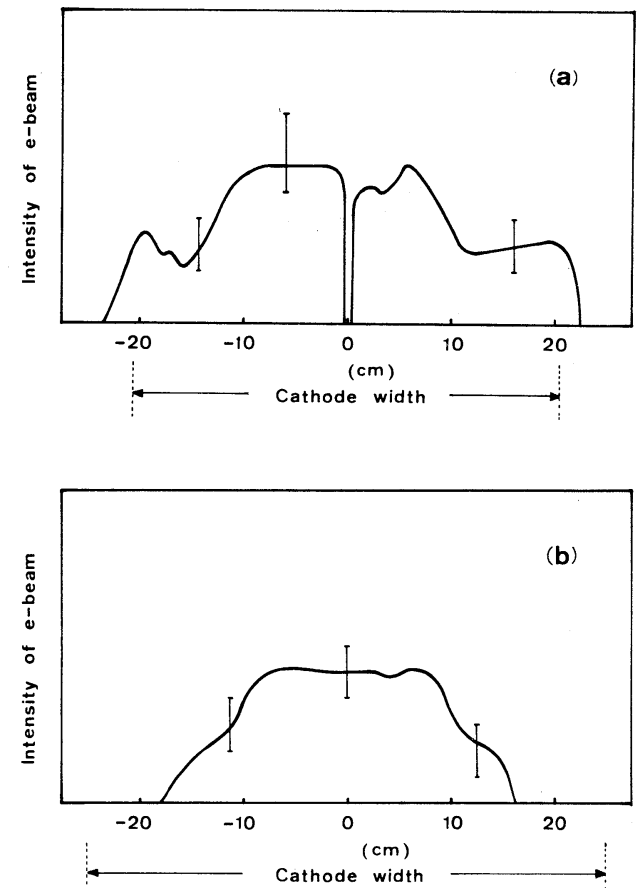

Fig. 9 Axial distribution of electron-beam transmitted through anode foil. (a) is for type $I$ and (b) is for type II .

I 型では電子ビームのレーザー気体中での飛 程に比べてアノード径が十分小さく，励起の均 一性を失うことはなかった。このことは均一な

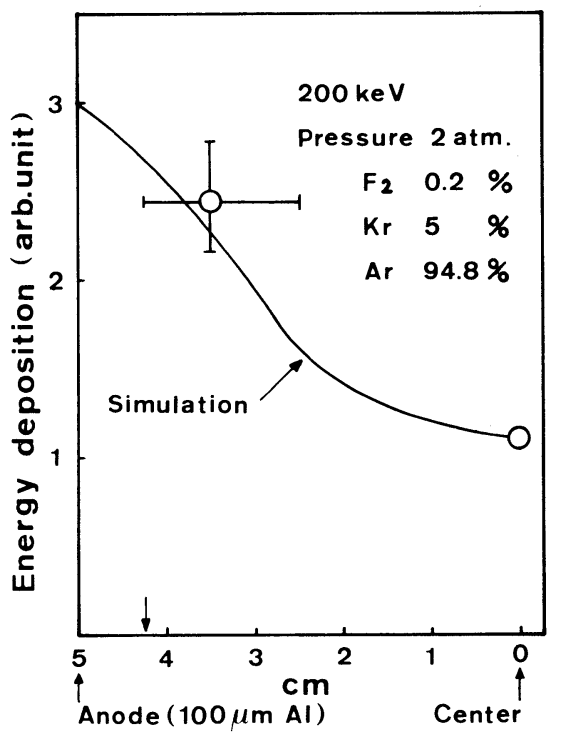

Fig. 10 Comparison of simulation and measurements for spatial profile of energy deposition. 
レーザーパターンが得られた事からも明らかで あった。従って励起の空間強度分布は开型レー ザー装置を使って測定し，シミュレーション結 果と比較した。その結果をFig. 10に示す。この 図においてダイオード電庄は $200 \mathrm{kV}$ でアノード として厚さ100 $\mu \mathrm{m}$ のアルミニウムを使用してい る。測定值は反射率の異なる出力ミラーを変え た場合のレーザー発振エネルギーの変化から概 算した小信号利得を表わしている。測定はアノ 一ドの中心と, 中心から $3.5 \mathrm{~cm}$ 離れた 2 点で行 なった。困で測定値の半径方向の誤差は出力ミ ラーの径に相当する。実線のシミュレーション 結果は励起強度の空間分布を表わしており，ア ノードの中心で測定值とシミュレーション結果 を規格化している。Fig. 10 よりこれらの間に は比較的良い一致が得られており, 励起強度の 空間分布を予測する際にこのシミュレーション 計算が重要な手段になり得ることを示している。

\section{3. $5 \mathrm{KrF}$ レーザー動作特性}

Fig. 11 に 型における電子ビームの電流波形 とレーザー発振波形を示す。共振器は曲率半径

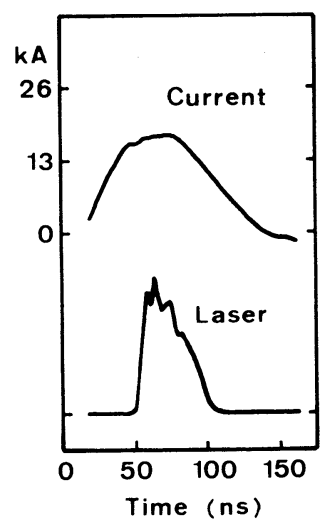

Fig. 11 Typical pulse forms of electron-beam current and $\mathrm{KrF}$ laser output for the type I device.

$4 \mathrm{~m}$ の全反射ミラーと石英板の表面反射を利用 した出力ミラーからなり, その間隔は $1.4 \mathrm{~m} て ゙$ ある。レーザー発振は電子ビーム電流が最大と なる領域で得られていて, 高利得レーザーのた めにレーザーの立上りが十分短い。次にアノー
ド膜厚 $50 \mu \mathrm{m}$ と $100 \mu \mathrm{m}$ の場合のレーザーガス圧 力変化に対するレーザー発振出力の変化をFig. 12 に示す。ガス混合比は $\left(\mathrm{F}_{2}, \mathrm{Kr}, \mathrm{Ar}\right)=(0.2 \%$, $8 \%, 91.8 \%)$ である。膜厚 $50 \mu \mathrm{m}$ の方がより高 出力が得られていて, これは膜厚が厚くなるに

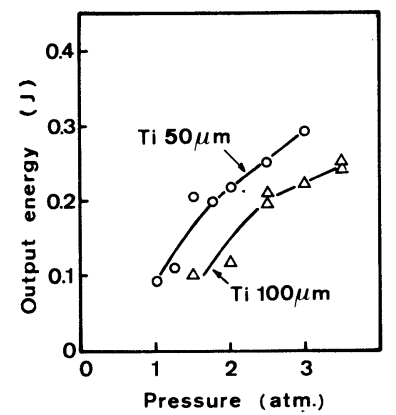

Fig. 12 Laser output energy as a function of the total gas pressure for the type I device for different thickness of the anode foil.

従って電子ビームの膜の透過率が悪くためであ る。最大レーザー出力はチタン膜厚 $50 \mu \mathrm{m}, 3$ 気 圧動作の時 $290 \mathrm{~mJ}$ (ビーム直径 $9 \mathrm{~mm}$ ) で, これ は取出エネルギー密度 $11 \mathrm{~J} / \mathrm{l}$ に相当する。また このI 型を増幅器として動作させ, 増幅・飽和 特性の測定を通して小信号利得 $17 \% / \mathrm{cm}$, 飽和

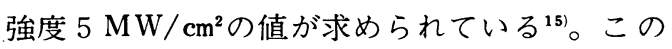
ときのアノード膜厚は $100 \mu \mathrm{m} て ゙ 2$ 気圧動作であ る。Fig. 13 は増幅実験から求められた小信号利 得 $g_{0}$ の時間変化 (○印) と電圧・電流波形を基に シミュレーションした単位体積当りの励起強度 $I_{\mathrm{p}}$ (実線) を示していて, これから測定範囲内

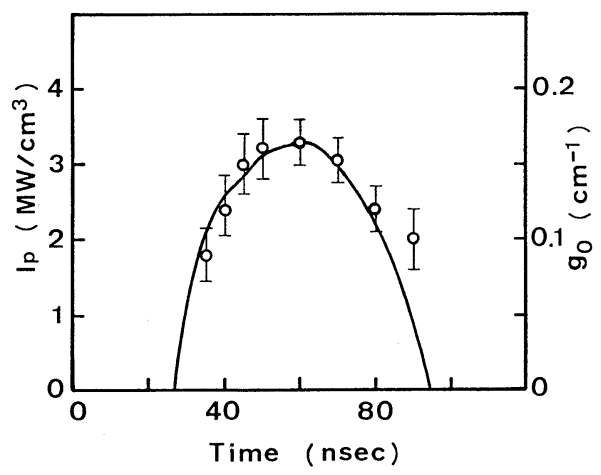

Fig. 13 Time dependence of the small signal gain coefficient (open circles) and the calculated pumping intensity (solid line). 


\section{4. むすび}

高出力・高効率KrFレーザーを開発するため に必要な基礎資料を得る事を目的として電子ビ 一ム励起レーザー装置を設計・試作した。その 動作特性の測定を通して明らかになった点をま とめると,

1） I 型において $400 \mathrm{keV} \cdot 25 \mathrm{kA}$, その改良 型の川型で $320 \mathrm{keV} ・ 65 \mathrm{kA}$ の電子ビームを 得た。川型はさらに高電圧化が可能である。

2）ダイオードインピーダンスは刃状の非一 様な電子ビーム源のために理想状態を仮定 した計算とは一致しない。

3）ダイオードインピーダンスはほぼ一定で, 電子ビームパルス時間内ではカソードプラ ズマの成長による影響は小さい。

4) インピーダン ス不整合に伴うアーク電流 の発生があり，これはインダクタンスによ る迂回路を設けることにより防止できる。

5）光軸方向の電子ビーム強度は I 型ではカ

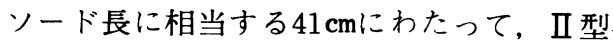

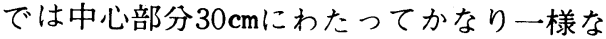
分布が得られた。しかし I 型，Ｉ型共に力 ソードの中心部分が強く, ビームピンチの 影響が見られた。

6）光軸断面の励起強度分布に関して，3 次 元モンテカルロ・コードによる計算と測定 結果との一致が見られ，このコードが大口 径高出力レーザーを設計する際の指針を与 え得る事がわかった。

今後 II 型レーザー装置の高出力化を進め, 短パ ルス・高出力レーザー光によるエネルギー取出

\section{参考献}

(1) For example, J. I. Levatter and R. S. Bradford, Jr. ; Appl. Phys. Lett. 33 (1978) 742.

( 2 ) M. Rokni, J. A. Mangano, J. H. Jacob, and J. C. Hsia ; IEEE J. Quantum Electron. 14 (1978) 464

（3）藤原, 加藤, 一村, 志水; レーザー研究 8 (1980) 524.

(4) C. A. Brau and J. J. Ewing; J. Chem. Phys. 63 (1975) 4640.

( 5 ) Y. Kubota, S. Kawasaki, A. Miyahara, and H. M. Saad; Japan. J. Appl. Phys. 13 (1974) 260.

(6) Alan C. Kolb; IEEE Transactions on Nuclear Science, NS- 22 (1975) 956.

( 7 ) J. A. Mangano and J. H. Jacob; Appl. Phys. Lett. 27 (1975) 495

( 8 ) D. J. Bradley, D. R. Hull, M. H. R. Hutchinson, and M. W. McGeoch;Opt. Commun. 14 (1975) 1.

(9) R. A. Gerber and E. L. Patterson; IEEE J. Quantum Electron. QE-11 (1975) 642.

(10) J. C. Martin; "Nanosecond Pulse Techniques" AWRE Report SSWA/JCM/709/49 UKEA, AWRE Aldermaston, England, P15 (April 1970) .

(11) L. G. Schlitt and L. P. Bradley ; (unpublished)

(12) J. G. Eden and D. Epp ; Rev. Sci. Instrum. 51 (1980) 781.

(13) I. Langmuir and K. T. Compton; Rev. Mod. Phys. 3 (1931) 191.

（14）根本，矢野；電子技術総合研究所軍 報42（1978） 363 .

(15) E. Friwiwara, Y. Kato, and C. Yamanaka ; Japan. J. Appl. Phys. 20 (1981). (to be published). 